\title{
The Effects of Management Skills on Job Satisfaction at Different Organizational Levels in Banks: The Role of Social Support and Self- Efficacy
}

\author{
Jalil Bagheri, Shahram Mirzaei Daryani*, Farzad Sattari Ardabili, Behnam Azadi, Majid \\ Ahmadlu
}

Department of Management, Ardabil Branch, Islamic Azad University, Ardabil, Iran

\begin{tabular}{|c|c|}
\hline & ABSTRACT \\
\hline $\begin{array}{l}\text { Keywords: } \\
\text { Self-efficacy, Social support, } \\
\text { Job satisfaction, Management } \\
\text { skills }\end{array}$ & $\begin{array}{l}\text { The current study aims to examine the effects of management skills on job satisfaction and } \\
\text { mediating role of self-efficacy and social support. To this end, } 236 \text { questionnaires have been } \\
\text { collected from managers of Tejarat bank. The results showed that, as individual self-efficacy } \\
\text { increases, social support cannot significantly mediate the relationship between management } \\
\text { skills and job satisfaction. However, managerial skills had a significant effect on employee's }\end{array}$ \\
\hline Received & job satisfaction. Also, social support significantly mediated the effects of management skill \\
\hline 5 January 2020 & on job satisfaction. Furthermore, self-efficacy reverses the effect of management skills on \\
\hline Received in revised form & job satisfaction. The results further revealed that in high levels of self-efficacy and high skills, \\
\hline 30 June 2020 & job satisfaction for management would be affected by other variables. The satisfaction in \\
\hline Accepted & higher level of organizations may need to be evaluated through different models rather than \\
\hline 01 July 2020 & rrent ones. \\
\hline
\end{tabular}

* Correspondence:

shahram.daryani@yahoo.com

CCIKD Publishing

Job satisfaction is one of the most challenging organizational concepts and a basis for management policies which is intended to increase organizational productivity and efficiency (Hooman, 2002) and job-related performance (Pouramini, Fayyazi, \& Ghasem-Gheshlaghi, 2018). There are several theoretical frameworks on job satisfaction in the literature, but they are often divided into three 
categories: content theories, process or discrepancy theories, and situational theories (Thompson, McNamara, \& Hoyle, 1997). Oskamp (1984) categorizes the theories of job satisfaction into needs, expectancy, and equity approaches. However, these theories can be more broadly categorized into micro-models and macro-models.

Micro-models include needs theories and cognitive theories and are mainly concerned with issues that the individual brings to the workplace. Hence, the basis for job satisfaction in these models is the satisfaction of internal driving forces in the workplace. These theories propose that the more psychological and cognitive needs are fulfilled, the more satisfied and productive will be an individual (Mitchell \& Larson, 1987).

One of the most recent theories of job satisfaction is Social Identity Theory (SIT). SIT posits that people classify themselves as belonging to various social categories based on age, gender, socioeconomic status, interests, skills, etc. It is the norm for an individual to be identified with multiple categories. Therefore, within the workplace, employees not only may identify themselves as part of an organization, but may also feel a sense of belonging to certain groups and not others within the organization (Brunetto \& Farr-Wharton, 2002). Hence, social support can be an effective driver of job satisfaction, which in turn leads to better performance (de Almeida, 2019). Similar to employees, managers must be satisfied with their job.

\section{Management Skills and Leadership Skills}

Some researchers have differentiated between the concepts of "management" from "leadership" (e.g., Bass, 1990; Katzenbach, 1995; Nair, 1994; Quinn, 2000; Tichy, 1999). One of the most popular models of leadership is based on the "Competing Values Framework," an organizing framework for leadership and managerial skills. It was developed by examining the criteria used to evaluate organizational and managerial performance (Cameron, Quinn, DeGraff, \& Thakor, 2006; Quinn \& Rohrbaugh, 1981). Cameron and Quinn (2006) argue that management skills fall into four clusters or categories: clan skills, adhocracy skills, market skills, and hierarchy skills. Individuals must be competent in these skills in order to be an effective manager. These skills are different from leadership skills. Based on previous theories, Analoui (1993) provided a model for management skills that comprised of three categories: task-related skills, people-related skills, and analytical and self-related skills. Task-related skills are those that enable managers to effectively manage the work at hand by determining objectives, forecasting, planning, and organizing the tasks involved. People-related skills such as communication, handling conflicts, motivating, leading, evaluating, and developing people are essential for people management. Analytical and self-related skills are necessary for managers' personal development. These include decision making and creative problem solving. Obviously, even the most talented of managers cannot perform at the highest level in all areas, and other factors such as social support and personal characteristics such as self-efficacy can be critical to their success.

\section{Work Self-Efficacy}

Bandura (1977) defined self-efficacy as "belief in one's ability to perform a task or more specifically to execute a specified behavior successfully." Self-efficacy also determines how much effort will be expended and how long it will be sustained in the face of obstacles or aversive experience. People with higher perceived self-efficacy attempt more at mastering a task and are less likely to 
give up or abandon it compared to individuals with lower perceived self-efficacy (Bandura \& Schunk, 1981; Schunk, 1981).

The relationship between work self-efficacy and organizational variables such as commitment and job satisfaction has been established in numerous studies. For example, Pethe, Chaudhary and Dhar (1999) suggested six dimensions for occupational self-efficacy, which they define it as the belief in one's ability and competence to perform in an occupation. These dimensions include confidence, command, adaptability, personal effectiveness, positive attitude, and individuality.

\section{Social Support}

Humans are social beings that interact with the society and its people and are always influenced by their environment. They need a help and support of others both in the time of need or crisis and in the time of happiness. The more extensive the social support, the better the mental health of the individual and the whole society. On the contrary, lack of social support will pose various challenges and cause irreparable damage to individuals (de Almeida, 2019).

One of the key functions of social networks is to provide social support among the members of a network. Social support can be defined as the perceived availability of people that care and confidence in people that can be counted on in the time of need and can make one feel better. Social support refers to the social network that provides psychological and material resources for individuals (Lincoln, 2000).

\section{The Proposed Model}

Figure 1 illustrates the theoretical framework of the study. In this model, management skills indirectly affect employees' job satisfaction through social support, and the relationship between social support and job satisfaction is mediated by self-efficacy. That is, the effect of social support on job satisfaction varies depending on employees' level of self-efficacy.

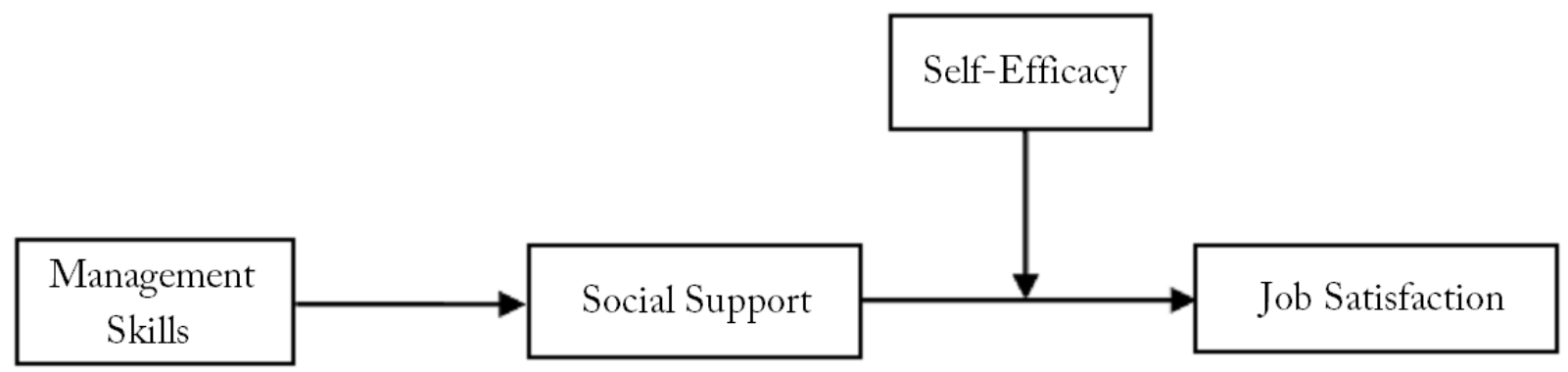

Figure 1. Theoretical framework of the study

The effects of self-efficacy and social support are undeniable in organizational behavior studies. These effects in each organizational level have not been studied to our best knowledge. The aim of the study is to show the effects of management skills on job satisfaction at different organizational levels in banks, considering the mediating effects of social support and self-efficacy. Accordingly, the present study addresses the following research questions:

1. To what extent do the management skills affect job satisfaction through mediating role of social support? 
2. Does self-efficacy moderate significantly the relationship between management skills on job satisfaction?

\section{Method}

\section{Population and Sample}

The population consisted of the managers of Tejarat Bank of Iran at different management levels: (1) staff managers, (2) provincial managers, (3) provincial deputies, (4) experts/inspectors, (5) heads/deputies of staff departments, (6) heads/deputies of branches, (7) heads/deputies of branch departments, and (8) employees/clerks. The sample was selected using quota sampling technique, and mass emailing was used to distribute the questionnaires. Totally, 267 questionnaires were distributed, of which 236 were completed and could be used for analysis. Table 1 shows the demographic characteristics of the respondents.

Table 1

Demographic Characteristics of the Respondents

\begin{tabular}{|c|c|c|c|}
\hline Age & $\%$ & Experience & $\%$ \\
\hline $20-30$ yrs. & 7.17 & $1-10$ yrs. & 11.31 \\
\hline $31-40$ yrs. & 43.05 & $11-20$ yrs. & 51.58 \\
\hline $41-50$ yrs. & 38.12 & $21-30$ yrs. & 34.39 \\
\hline $51-60$ yrs. & 21.11 & $>30$ yrs. & 2.71 \\
\hline$>60$ yrs. & 0.45 & & \\
\hline Education & $\%$ & Position & $\%$ \\
\hline High school diploma & 8.97 & Staff manager & 1.35 \\
\hline Associate's/bachelor's degree & 38.57 & Provincial manager & 2.70 \\
\hline Master's degree & 47.53 & Provincial deputy & 0.90 \\
\hline \multirow[t]{5}{*}{$\mathrm{PhD}$} & 4.93 & Experts/inspectors & 8.56 \\
\hline & & Head/deputy of staff department & 5.86 \\
\hline & & Branch manager & 22.97 \\
\hline & & Head/deputy of branch department & 15.77 \\
\hline & & Employee/clerk & 41.89 \\
\hline Gender & $\%$ & & \\
\hline Male & 73.42 & Female & 26.58 \\
\hline
\end{tabular}

\section{Job Satisfaction Scale}

The job satisfaction questionnaire consisted of 5 items and was adopted from the Quality of Employment Survey of Quinn and Shepard (1974). This instrument contains general items about job satisfaction that can be generalized to all professions (Holt \& Belvins, 2011), and measures general feelings of job satisfaction. A score of 5 indicates the lowest level of satisfaction and a score of 16 indicates the highest level of satisfaction.

\section{Management Skills Scale}

The 21-item questionnaire of Analoui, Labbaf, and Noorbakhsh (2000) was used to measure management skills. These items were rated on a five-point Likert scale from 1 for 'the least important' to 5 for 'the most important'. Managing teamwork, effective decision making, and effective communication were some of the dimensions in this instrument. 


\section{Social Support Scale}

Perceived social support is "an exchange of resources between at least two individuals perceived by the provider or the recipient to be intended to enhance the well-being of the recipient" (Shumaker \& Brownell, 1985). This concept was measured using the Social Support scale of De Jong, De Ruyter and Wetzels (2005). An example item in this questionnaire is "In our bank, colleagues can always count on each other for support."

\section{Generalized Self-Efficacy Scale}

The Generalized Self-Efficacy (GSE) scale of Schwarzer and Jerusalem (1995) was used to measure this concept. The scale was originally developed and published in German and has since been translated into more than 33 languages. It has been tested in various countries with wellestablished validity. GSE measures the ability to cope with daily hassles and adapt to various stressful life experiences. It consists of ten items rated on a four-point scale ranging from 'not at all true' to 'exactly true'. Higher scores indicate higher self-efficacy.

\section{Data Analysis}

Content validity, construct validity, and criterion validity were used to measure the validity of the instrument. Content validity of the scales and the items has been established in the literature. Here, Confirmatory Factor Analysis (CFA) and Cronbach's alpha were used to evaluate the validity and reliability of the instrument. As shown in Table 3, all the scales are valid and reliable to be used. Kaiser-Meyer-Olkin (KMO) measure of sampling adequacy and Bartlett's test of sphericity were used to examine the fitness of factor analysis. Principal components analysis and Varimax rotation were used for factor analysis to reduce data to the number of factors and simplify solutions. Only factors with eigenvalues higher than 1 (Kaiser, 1958) and variables with factor loadings higher than 0.5 were used. Since the data for both dependent and independent variables were taken from the same source, single-factor test (Podsakoff, MacKenzie, Lee, \& Podsakoff, 2003) was used to avoid common method variance.

The measurement model was evaluated using CFA, where items are allowed to load onto their respective constructs. Several goodness-of-fit indices, as suggested in structural equation modeling, were applied to assess the research model fit (Kline, 2015). These included: chi-square/degrees of freedom ratio $\left(\chi^{2} / d f\right)$, which should be less than 3; relative fit index (RFI), normed fit index (NFI), comparative fit index (CFI), and Tucker-Lewis coefficient (TLI). RFI, NFI, CFI, and TLI higher than 0.90 is also recommended. RMSEA was another index should reach 0.05 and is acceptable up to 0.08 .

To avoid data entry errors, data were entered twice and the two entries were compared (Barchard $\&$ Christensen, 2007). Table 2 and 3 provides a summary of the descriptive statistics for the variables, their correlations, and the results of CFA. 
Table 2

\begin{tabular}{|c|c|c|c|c|c|c|c|c|}
\hline Variables & 1 & 2 & 3 & 4 & 5 & 6 & 7 & Reliability Coefficient \\
\hline Gender & - & & & & & & & - \\
\hline Marital Status & 0.03 & -- & & & & & & - \\
\hline Education & 0.07 & -0.03 & - & & & & & - \\
\hline Social Support & 0.18 & 0.19 & -0.17 & - & & & & 0.87 \\
\hline Job Satisfaction & 0.14 & 0.02 & -0.07 & $0.46^{* *}$ & - & & & 0.78 \\
\hline Management Skills & -0.04 & 0.13 & -0.10 & $0.47 * *$ & $0.34 * *$ & - & & 0.82 \\
\hline Self-Efficacy & 0.13 & -0.06 & 0.15 & $0.38 * *$ & $0.45^{* *}$ & $0.198 *$ & - & 0.80 \\
\hline
\end{tabular}

* Correlation is significant at $p<0.01$,

** Correlation is significant at $p<0.05$

Table 3

CFA Results

\begin{tabular}{|c|c|c|}
\hline Subscale & Item & $\begin{array}{l}\text { Factor } \\
\text { Loading }\end{array}$ \\
\hline \multirow[t]{2}{*}{ Self-Efficacy } & I can always solve difficult problems if I try hard enough. & .73 \\
\hline & If someone opposes me, I can find the means and ways to get what I want. & $\mathrm{n} / \mathrm{a}$ \\
\hline $\mathrm{NFI}=.91$ & It is easy for me to stick to my aims and accomplish my goals. & .68 \\
\hline $\mathrm{FI}=.91$ & I am confident that I could deal efficiently with unexpected events. & .78 \\
\hline $\mathrm{TLI}=.91$ & Thanks to my resourcefulness, I know how to handle unforeseen situations. & .64 \\
\hline $\mathrm{CFI}=.91$ & I can solve most problems if I invest the necessary effort. & .61 \\
\hline RMSEA $=.08$ & I can remain calm when facing difficulties because I can rely on my coping abilities. & .88 \\
\hline$\chi^{2}=8.41$ & When I am confronted with a problem, I can usually find several solutions. & 63 \\
\hline \multirow[t]{2}{*}{$\boldsymbol{p}=.08$} & If I am in trouble, I can usually think of a solution. & .74 \\
\hline & I can usually handle whatever comes my way. & .79 \\
\hline Management Skills & Task-related skills & .79 \\
\hline $\mathrm{NFI}=.92$ & People-related skills & .94 \\
\hline $\mathrm{FI}=.95$ & Analytical and self-related skills & .88 \\
\hline \multicolumn{3}{|l|}{$\mathrm{TLI}=.92$} \\
\hline \multicolumn{3}{|l|}{$\mathrm{CFI}=.95$} \\
\hline \multicolumn{3}{|l|}{ RMSEA $=.08$} \\
\hline \multicolumn{3}{|l|}{$\chi^{2}=11.21$} \\
\hline \multicolumn{3}{|l|}{$p=.07$} \\
\hline Job Satisfaction & All in all, how satisfied would you say you are with your job? & .69 \\
\hline $\mathrm{NFI}=.96$ & $\begin{array}{l}\text { Knowing what you know now, if you had to decide all over again whether to take the job you now have, } \\
\text { what would you decide? }\end{array}$ & .84 \\
\hline $\mathrm{FI}=.98$ & In general, how does your job measures up to the sort of job you wanted when you took it? & .85 \\
\hline $\mathrm{TLI}=.96$ & If a good friend of yours told you they were interested in working in a job like yours for your employer, & \\
\hline $\mathrm{CFI}=.98$ & what would you tell them? & .75 \\
\hline RMSEA $=.08$ & If you were free to go into any type of job you wanted, what would your choice be? & \\
\hline \multicolumn{3}{|l|}{$p=.08$} \\
\hline Social Support & In our bank, colleagues can always count on each other for support. & .90 \\
\hline $\mathrm{NFI}=.96$ & Each member of the bank is involved with what is going on in the bank. & .92 \\
\hline $\mathrm{FI}=.98$ & In our bank, members are always willing to help each other. & .87 \\
\hline \multicolumn{3}{|l|}{$\mathrm{TLI}=.96$} \\
\hline \multicolumn{3}{|l|}{$\mathrm{CFI}=.98$} \\
\hline \multicolumn{3}{|l|}{ RMSEA $=.08$} \\
\hline \multicolumn{3}{|l|}{$\chi^{2}=9.61$} \\
\hline $\boldsymbol{p}=.08$ & & \\
\hline
\end{tabular}




\section{Results}

\section{Testing the Hypotheses}

Table 4 shows the results of testing the first hypothesis, which predicts that the effect of management skills on job satisfaction is mediated by social support. PROCESS Model 4 (Hayes, 2013) was used to test the mediating role of social support. Table 4 shows the outputs along with 95\% bias-corrected bootstrap confidence intervals (CI) on the basis of 5000 bootstrap samples.

Table 4

Social Support Mediating the Effects of Management Skills on Job Satisfaction

\begin{tabular}{llll}
\hline & \multicolumn{3}{c}{ Job Satisfaction } \\
\cline { 2 - 4 } & $\beta$ & $S E$ & $t$ \\
\hline Constant & 3.63 & 0.72 & $4.92^{* * * * *}$ \\
Management Skills & 0.20 & 0.10 & $2.00^{* *}$ \\
Social Support & 0.05 & 0.02 & $2.49^{* * *}$ \\
Management Skills $\times$ Social Support & 0.10 & 0.05 & $1.77^{* *}$ \\
& $\mathrm{~F}=6.79$ & & $R^{2}=0.16^{* * *}$ \\
\hline$* \mathrm{P}<0.10 ; * * \mathrm{P}<0.05 ; * * * \mathrm{P}<0.01 ; * * * * \mathrm{P}<0.001$ & & &
\end{tabular}

The results in Table 4 show that management skills have a significant effect on job satisfaction and that managers can leverage their skills to improve employee's job satisfaction $(\beta=0.20, t=$ $2.00,95 \%$ CI $[0.41,0.87], p=.04)$. The results also indicate that social support has a significant effect on job satisfaction. The coefficient $\beta$ is .05 and t-value is 2.49. Inclusion of social support in the relationship between management skills and job satisfaction lessens the effect of management skills, but the mediation effect of social support is still significant $(\beta=.10, t=1.77)$. Therefore, social support significantly mediates the effect of management skills on job satisfaction in bank employees.

Table 5 shows the results of testing the second hypothesis. According to this hypothesis, employees' generalized self-efficacy moderates the effect of management skills on job satisfaction, which is mediated by social support. PROCESS Model 14 (Hayes, 2013) was used to test this hypothesis.

Table 6

Mediating-moderating Effect of Self-efficacy

\begin{tabular}{llll}
\hline & \multicolumn{2}{c}{ Job Satisfaction } \\
\cline { 2 - 4 } & $\beta$ & $S E$ & $t$ \\
\hline Constant & 3.02 & 0.36 & $8.31^{* * *}$ \\
Social Support & 0.04 & 0.00 & $4.18^{* * *}$ \\
Management Skills & 0.13 & 0.07 & $1.87^{*}$ \\
Self-Efficacy & 0.18 & 0.11 & 1.72 \\
Management Skills $\times$ Social Support $\times$ & -0.27 & 0.10 & $-2.71^{* *}$ \\
Self-Efficacy & & & $R^{2}=0.22^{* * * *}$ \\
& $\mathrm{~F}(5,101)=9.95$ & &
\end{tabular}

The results show that although high levels of management skills have a significant effect on employee's job satisfaction and that this effect is mediated by social support, the inclusion of employee's self-efficacy reverses the effect of management skills on job satisfaction. That is, as individual self-efficacy increases, social support cannot significantly mediate the relationship between management skills and job satisfaction. 


\section{Conclusion}

This research examined the effect of management skills on job satisfaction in banks. This effect was evaluated with the mediating role of social support and the moderating role of employee's selfefficacy. High levels of social support is a key factor in job satisfaction (Bradley \& Cartwright, 2012; Dixon, 2012) that significantly mediates the effect of management skills on job satisfaction, such that management skills play a greater role in increasing employee's satisfaction with the job in an environment that fosters social support. In addition, social support does not affect everyone equally (Etzion, 1984), and its effect is mediated or moderated by a variety of factors, including stress (de Almeida, 2019; Finney, Mitchell, Cronkite, \& Moos, 1984; Williams et al., 2008). Effect of social support on job satisfaction can vary depending on the individual's level of self-efficacy, individuals with higher levels of self-efficacy.

\section{Acknowledgement}

This paper is extracted from a PhD thesis titled "Designing Model of managers general skills of Tejarat Bank northwest Iran's," in Islamic Azad University of Ardabil Branch supervised by Shahram Mirzaei Daryani and Farzad Sattari Ardabili, as supervisors and Behnam Azadi, Majid Ahmadlu as the advisors. The authors appreciate participants and respondents to the questionnaire.

\section{References}

Analoui, F. (1993). Skills of Management. In J. W. Cusworth \& T. R. Franks (Eds), Managing projects in developing Countries. Harlow: Longman Scientific and Technical.

Analoui, F., Labbaf, H., \& Noorbakhsh, F. (2000). Identification of clusters of managerial skills for increased effectiveness: The case of the steel industry in Iran. International Journal of Training and Development, 4(3), 217-234.

Bandura, A. (1977). Self-efficacy: toward a unifying theory of behavioral change. Psychological Review, 84(2), 191-215.

Bandura, A., \& Schunk, D. H. (1981). Cultivating competence, self-efficacy, and intrinsic interest through proximal selfmotivation. Journal of Personality and Social Psychology, 41(3), 586-598.

Barchard, K. A., \& Christensen, M. M. (2007). Dimensionality and higher-order factor structure of self-reported emotional intelligence. Personality and Individual Differences, 42(6), 971-985.

Bass, B. (1990). Handbook of leadership: Theory, research, and managerial applications, 3rd ed. New York: Macmillan.

Bradley, J. R., \& Cartwright, S. (2002). Social support, job stress, health, and job satisfaction among nurses in the United Kingdom. International Journal of Stress Management, 9(3), 163-182.

Brunetto, Y., \& Farr-Wharton, R. (2002). Using social identity theory to explain the job satisfaction of public sector employees. The International Journal of Public Sector Management, 15(7), 534-555.

Cameron, K. S., \& Quinn, R. E. (2006). Diagnosing and changing organizational culture. San Francisco: Jossey-Bass. 
Cameron, K. S., Quinn, R. E., DeGraff, J., \& Thakor, A. V. (2006). Competing values leadership: Creating value in organizations. New York: Edward Elgar.

de Almeida, M. H. (2019). Role stress, social support, job satisfaction. Behavior Studies in Organizations, 1, 25-36.

De Jong, A., De Ruyter, K., \& Wetzels, M. (2005). Antecedents and consequences of group potency: A study of self-managing service teams. Management Science, 51(11), 1610-1625.

Dixon, N. W. (2012). Truly accomplished: Effectiveness of a measurement and feedback approach to lifestyle change (Published doctoral dissertations). 2004-2019. 2121. Retrieved from https://stars.library.ucf.edu/etd/2121

Etzion, D. (1984). Moderating effect of social support on the stress-burnout relationship. Journal of Applied Psychology, 69(4), 615-622.

Finney, J. W., Mitchell, R. E., Cronkite, R. C., \& Moos, R. H. (1984). Methodological issues in estimating main and interactive effects: Examples from coping/social support and stress field. Journal of Health and Social Behavior, 25(1), 85-98.

Hayes, A. F. (2013). Methodology in the social sciences. Introduction to mediation, moderation, and conditional process analysis: A regression-based approach. New York: Guilford Press.

Holt, T. J., \& Blevins, K. R. (2011). Examining job stress and satisfaction among digital forensic examiners. Journal of Contemporary Criminal Justice, 27(2), 230-250.

Hooman, H. (2002). Development and standardization of a job satisfaction measurement scale. 1st Edition. Tehran: Public Administration Training Center.

Kaiser, H. F. (1958). The varimax criterion for analytic rotation in factor analysis. Psychometrika, 23(3), 187-200.

Katzenbach, J. R. (1995). Real change leaders: How you can create growth and high performance in your company. New York: New York Times Business, Random House.

Kline, R. B. (2015). Principles and practice of structural equation modeling. Guilford publications.

Lincoln, K. D. (2000). Social support, negative social interactions, and psychological well-being. Social Service Review, 74(2), 231-252.

Mitchell, R. T., \& Larson, J. R. (1987). People in organizations. McGraw-Hill Inc., US.

Nair, K. (1994). A higher standard of leadership. San Francisco: Barrett-Koehler.

Nasseh, M., Ghazinour, M., Joghataei, M. T., Nojomi, M., \& Richter, Y. (2011). A Persian version of the social support questionnaire (SSQ). Social Welfare Research Quarterly, 11(41), 251-266.

Oskamp, S. (1984). Applied social psychology. Englewood Cliffs, NJ: Prentice-Hall.

Pethe, S., Chaudhary, S., \& Dhar, U. (1999). Occupational self-efficacy scale and manual. Agra, India: National Psychological Corporation.

Podsakoff, P. M., MacKenzie, S. B., Lee, J. Y., \& Podsakoff, N. P. (2003). Common method biases in behavioral research: A critical review of the literature and recommended remedies. Journal of Applied Psychology, 88(5), 879-903.

Pouramini, Z., Fayyazi, M., \& Ghasem-Gheshlaghi, M. Y. (2018). The Relation between Hope and Pliability with Job Satisfaction and Organizational Citizenship Behavior, Management and Business Research Quarterly, 7, 21-27.

Quinn, R. E. (2000). Change the world. San Francisco: Jossey-Bass.

Quinn, R. E., \& Rohrbaugh, J. (1981). A competing values approach to organizational effectiveness. Public Productivity Review, 122-140.

Quinn, R. P., \& Shepard, L. J. (1974). the 1972-73 quality of employment survey: Descriptive statistics, with comparison data from the 1969-70 survey of working conditions. University of Michigan: Institute for Social Research. 
Schunk, D. H. (1981). Modeling and attributional effects on children's achievement: A self-efficacy analysis. Journal of Educational Psychology, 73(1), 93-105.

Schwarzer, R., Jerusalem, M., Weinman, J., Wright, S., \& Johnston, M. (1995). Measures in health psychology: A user's portfolio. Causal and control beliefs. Windsor, UK: Nfer-Nelson, 35-7.

Shumaker, S. A., \& Brownell, A. (1985). Introduction: Social support interventions. Journal of Social Issues, 41(1), 1-4.

Thompson, D. P., McNamara, J. F., \& Hoyle, J. R. (1997). Job satisfaction in educational organizations: A synthesis of research findings. Educational Administration Quarterly, 33(1), 7-37.

Tichy, N. M. (1999). The leadership engine. New York: Harper Business.

Williams, L., O'Connor, R. C., Howard, S., Hughes, B. M., Johnston, D. W., Hay, J. L., ... \& Grealy, M. A. (2008). Type-D personality mechanisms of effect: the role of health-related behavior and social support. Journal of Psychosomatic Research, 64(1), 63-69. 